PhD (Economics), Associate Professor,Associate Professor of Commercial, Trade and Entrepreneurship Department National Technical University «Kharkiv Polytechnic Institute»; e-mail: serhelenka@gmail.com; ORCID ID: 0000-0002-9796-9218

Morozova Nadiya L.,

PhD in Economics,Associate Professor, Associate Professor, Banking University, Kharkiv educational-scientific institute;

Ukraine; e-mail: morozova.nadiya@khibs.ubs.edu.ua e-mail: morozova.nadiya@khibs.ubs.edu; ORCID ID: 0000-0002-4082-2960

Karpets Olga S., PhD in Economics, Associate Professor of Economic and Finance Department Zakhidnodonbaskyi Instytut Inter-regional Academy of Personnel Menegment; e-mail: karpets_olya@ukr.net; ORCID ID: 0000-0002-9152-4154

Babenko Maksym V., lecture Finance, Banking and Insurance Department, Banking University, Kharkiv educational-scientific institute; e-mail: babenkomv2011@gmail.com; ORCID ID: 0000-0001-6792-3465

\title{
MODEL ASPECTS OF EVALUATING EFFICIENCY OF THE PERSONNEL MANAGEMENT AND MOTIVATION
}

Annotation. This paper proposes methodological aspects of evaluation of organization efficiency of personnel management and motivation on the bases of application of economic and mathematical tools by implementing a three-component algorithmic model. The structural divisions heads' work effectiveness evaluation is carried out on the basis of econometric systems of structural equations that allow you to rank personality, communicative, innovative, social and corporate managers characteristics that have the greatest impact on the overall performance indicators of the bank staff among which are considered amount of attracted funds; assessment of employee's compliance with the standard; activity efficiency (number of contracts); contribution to development. The obtained modeling results confirm the hypothesis that structural unit managers need to work on the development of their communicative, innovative, personal and social characteristics. Models for analyzing the personnel motivation factors on the bases of the methodology of multivariate statistical factor analysis with initial list of 13 main indicators of staff motivation are proposed; as a result, we set up the aggregated factors that reflect the properties of several motivational components such as financial, social incentives and medical insurance for employees. The model for estimating influence of motivation factors on results of bank's activity on the bases of nonlinear econometric functions is constructed. The regression equation of the motivation factors influence on the bank total profit is obtained. The proposed model toolkit for evaluation of efficiency of management and staff motivation will allow the bank's management to improve motivation and incentives mechanisms in order to raise efficiency of stuff productivity in direction of increasing bank profitability and competitiveness.

Key words: bank, motivation, personnel, model, structural equations, main components, nonlinear modeling, adequacy, staff efficiency.

Formula: 4; Fig.: 9; Table: 3; Bibl.: 15.

Сергієнко О. А.

к.е.н., доиент, доиент кафедри комериійної, торгівельної та підприємницької діяльності; Національний технічний університет «Харківський політехнічний інститут»; e-mail: serhelenka@gmail.com; ORCID ID: 0000-0002-9796-9218 
Морозова Н. Л.

к.е.н.,доцент кафедри фінансів, банківської справи та страхування; ДВНЗ «Університет банківської справи», Харківський навчально-науковий інститут; e-mail: morozova.nadiya@khibs.ubs.edu; ORCID ID: 0000-0002-4082-2960

Карпець О. $C$. к.е.н.,дочент кафедри економіки та фінансів; Західнодонбаський інститут Міжрегіональної Академії управління персоналом; e-mail: karpets_olya@ukr.net; ORCID ID: 0000-0002-9152-4154

Бабенко М. В.

старший викладач кафедри фінансів, банківської справи та страхування; ДВНЗ «Університет банківської справи», Харківський навчально-науковий інститут; e-mail: babenkomv2011@gmail.com; ORCID ID: 0000-0001-6792-3465

\section{МОДЕЛЬНИЙ АСПЕКТ ОЦНКИ ЕФЕКТИВНОСТІ ОРГАНІЗАЦІЇ УПРАВЛІННЯ ТА МОТИВАЦЇ̈ ПЕРСОНАЛУ}

Анотація. У статті запропоновано методологічні аспекти оцінки ефективності організації управління персоналом та мотивації на основі застосування економікоматематичного інструментарію шляхом реалізації трьохкомпонентної алгоритмічної моделі. Здійснено оцінку ефективності праці керівників структурних підрозділів на основі економетричних систем структурних рівнянь, що дозволяють ранжувати особистісні, комунікативні, інноваційні, соціальні та корпоративні характеристики, які в найбільшій мірі впливають на загальні показники ефективності роботи персоналу банку, серед яких розглядаються обсяг залучених коштів; оцінка працівника щодо відповідності стандарту; ефективність діяльності (кількість контрактів); вклад у розвиток. Отримані результати підтверджують гіпотезу, що керівникам структурних підрозділів треба працювати над розвитком своїх комунікативних, інноваційних, особистих та соціальних характеристик. Запропоновані моделі аналізу факторів мотивації персоналу за методологією багатовимірного статистичного факторного аналізу на основі вихідного переліку 313 основних показників мотивації персоналу, у результаті чого сформовані агреговані фактори, що відбивають властивості декількох мотиваційних компонентів, а саме: матеріального стимулювання робітників, соціального стимулювання та охорони здоров'я персоналу. Побудовано модель оцінки впливу факторів мотивації на результати діяльності банку на основі нелінійних економетричних функцій. Отримано регресійне рівняння впливу факторів мотивації на загальний прибуток банку.Запропонований модельний інструментарій оцінювання ефективності управління та мотивації персоналу дозволить керівництву банку вдосконалити механізми стимулювання та заохочення працівників 3 метою підвищення ефективності їх праці в напрямі підвищення прибутковості та конкурентоспроможності банку.

Ключові слова: банк, мотивація, персонал, модель, структурні рівняння, головні компоненти, нелінійне моделювання, адекватність, ефективність персоналу.

Формул: 4; рис.: 9; табл.: 3; бібл.: 15.

Сергиенко Е. $A$. к.э.н., доиент, доиент кафедры коммерческой, торговой и предпринимательской деятельности; Национальный технический университет «Харьковский политехнический институт»; e-mail: serhelenka@gmail.com; ORCID ID: 0000-0002-9796-9218

Морозова Н. Л. к.э.н., доцент кафедры финансов, банковского дела и страхования; ГВУЗ «Университет банковского дела», Харьковский учебно-научный институт, e-mail: morozova.nadiya@khibs.ubs.edu; ORCID ID: 0000-0002-4082-2960 
Kapneщ O. C.

к.э.н., дочент кафедры экономики и финансов,

Западнодонбасский институт Межрегиональной Академии управления персоналом,

e-mail: karpets_olya@ukr.net; ORCID ID: 0000-0002-9152-4154

Бабенко М. В.

стариий преподаватель кафедры финансов, банковского дела и страхования ГВУЗ «Университет банковского дела», Харьковский учебно-научный институт, e-mail: babenkomv2011@gmail.com; ORCID ID: 0000-0001-6792-3465

\section{МОДЕЛЬНЫЙ АСПЕКТ ОЦЕНКИ ЭФФЕКТИВНОСТИ ОРГАНИЗАЦИИ УПРАВЛЕНИЯ И МОТИВАЦИИ ПЕРСОНАЛА}

Аннотация. В статье предложены методологические аспекты оценки эффективности организации управления персоналом и мотивации на основе применения экономикоматематических методов и моделей. Осуществлена оценка эффективности труда руководителей структурных подразделений на основе эконометрических систем структурных уравнений. Предложенные модели анализа факторов мотивации персонала на основе факторного анализа в результате чего сформированы агрегированные факторы, отражающие свойства нескольких мотивационных компонент, а именно: материального стимулирования работников, социального стимулирования и охраны здоровья персонала. Построена модель оценки влияния факторов мотивации на результаты деятельности банка на основе нелинейных эконометрических функций. Предложенный модельный инструментарий оценки эффективности управления и мотивации персонала позволит руководству банка усовершенствовать механизмы мотивации и стимулирования с целью повышения эффективности их работы в направлении повышения прибыльности и конкурентоспособности банка.

Ключевые слова: банк, мотивация, персонал, модель, структурные уравнения, главные компоненты, нелинейное моделирование, адекватность, эффективность персонала.

Формул: 4; рис.: 9; табл.: 3; библ.: 15.

Introduction. The level of development of banking institution depends to a large extent on efficiency of work of the personnel, which is a decisive factor in competition in the market. That is why, under current exit of the banking system from the financial crisis, intensification of competition for redistribution of the bank capital market, the problem of efficient management of the bank's labor resources and provision of conditions for continuous increase of efficiency of banking personnel becomes a special issue. Labor productivity will increase only if management stimulates use of creative abilities of all categories of employees both materially and mentally, shows interest in their personal problems, promotes creation and maintenance of a favorable social microclimate, within limits of its powers and capabilities of bank, carries out social protection of people, guarantees them employment, occupational safety and health, etc $[3,6,7,11]$.

Analysis of research and problem statement. Issues of improving efficiency and productivity of bank's staff, which are closely linked to the urgent problem of the present - ensuring sustainable economic development of Ukraine, are investigated by such researchers as P. Buryak, M. Grigorieva [5], N. Yesinova, O. Grishnova, A. Kalina, S. Kalinina, B. Karpinsky [8, 9], S. Kozmenko, N. Lukyanchenko, T. Mazilo, M. Paladiy, A. Cherep [15] and others. However, a number of issues related to personnel management in the bank remain unresolved, which becomes particularly important in the context of the reform of financial and banking institutions [4]. The urgency of the problem under investigation necessitates the focus of attention in the study on the ways and methods of forming an effective system of personnel management of the banking institution, and especially on the application of mathematical methods and models.

Research results. Motivation of labor is an important factor in the effectiveness of work. Knowing what drives a person to work, which motives lie at the heart of her actions, you can develop an effective system of labor stimulating $[10,12]$. In this regard, the research paper proposes 
to improve methodological tools for assessing effectiveness of organization of personnel management and motivation based on application of economic and mathematical methods and models, general algorithm of study of which is shown in Fig. 1. Let's have a look at the results of the implementation of the proposed algorithm on the basis of the activity data of PJSC "Ukrsotsbank" [13] step by step.

Step 1 - Estimation model of work efficiency of structural divisions heads based on structural equations. This stage involves the construction of a model that reflects the relationship between personal characteristics of manager and performance indicators of bank. Thus, based on dynamics data of PJSC "Ukrsotsbank" for 15 years (2002 - 2016), exogenous (independent) and endogenous (dependent) variables are determined.

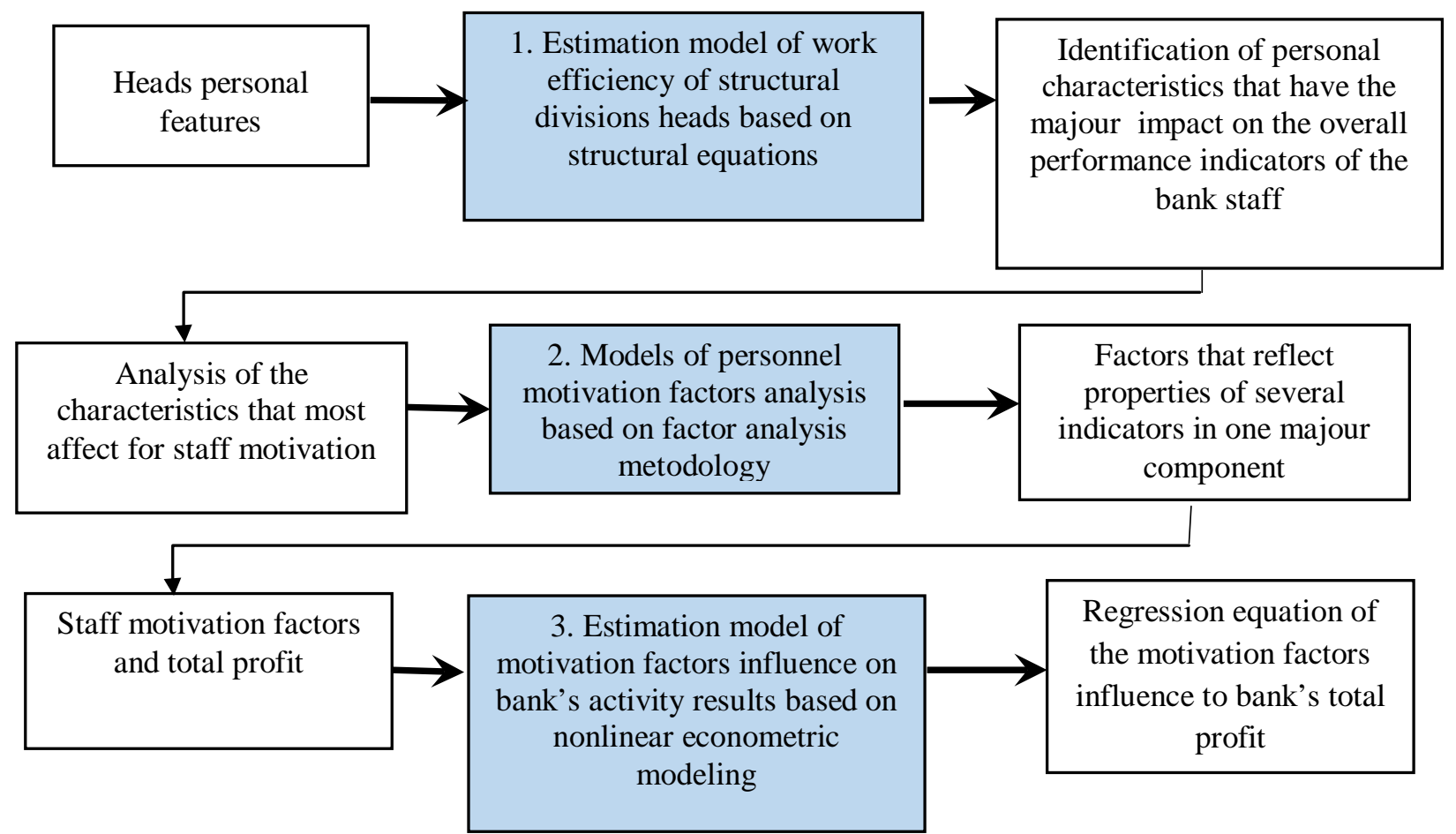

Fig. 1. Algorithm of evaluation of organization efficiency of personnel management and motivation on the bases of application of economic and mathematical methods and models

The following variables were assigned to the independent variables [13]: $X 1$ - personality characteristics of the manager; $X 2$ - communicative characteristic; $X 3$-innovative characteristic; $X 4$ - social characteristics; $X 5$ - corporate characteristics. Dependent variables: $Y 1$ - amount of funds attracted; $Y 2$ - employee's assessment of compliance with the standard; $Y 3$ - activity efficiency (number of contracts); Y 4 - contribution to development.

To construct the model, modeling by means of structural equations was chosen, since the model for assessing the quality labor of a head of a structural unit of the bank is described by a system of equations, in which both exogenous and endogenous variables are associated with complex dependencies. Modeling by structural equations is a powerful technique of multidimensional statistical analysis, which allows us to trace effect of changes in exogenous variables on the value of endogenous variables [14]. The system of equations reflecting dependence, between exogenous and endogenous variables, will look like: 


$$
\left\{\begin{array}{l}
Y_{1}=f\left(x_{1}, x_{3}, y_{4}\right) \\
Y_{2}=f\left(x_{1}, x_{3}, x_{4}, y_{1}, y_{3}, y_{4}\right) \\
Y_{3}=f\left(x_{1}, x_{2}, x_{5}\right) \\
Y_{4}=f\left(x_{1}, x_{2}, x_{5}, y_{2}\right)
\end{array}\right.
$$

The ways diagram of the structural equations system is shown in Fig. 2.

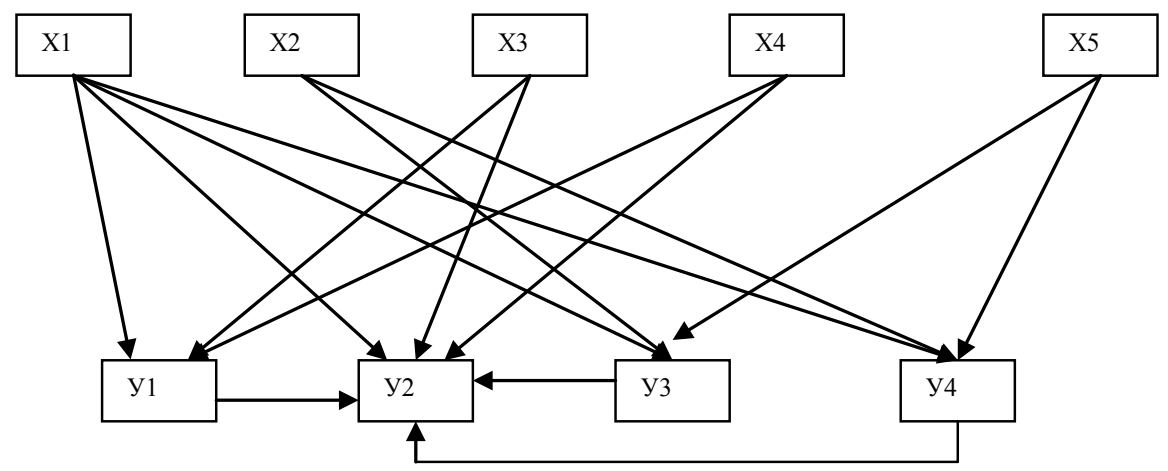

Fig. 2. Ways diagram of the quality assessment model of a bank structural unit heads

When constructing the model, the STATISTICA module SEPATH $[1,14]$ is used to evaluate the quality of fitting the model with various indexes: the Steigard-Linde index, the Gamma-index, the McDonald's index, the Jöreskog-Sörbom index, the Akaike index, and others [14]. In fig. 3 results of structural modeling are presented (in the upper left of the window the information about the results of the evaluation, in the window right part are simulation results, evaluation of fit and adequacy).

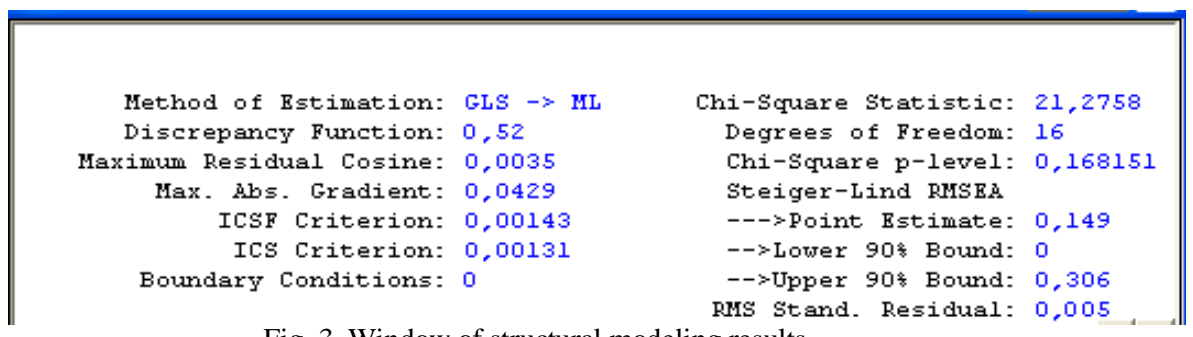

Fig. 3. Window of structural modeling results

The resulting system in analytical form looks as follows:

$$
\left\{\begin{array}{l}
Y_{1}=0.862 \cdot x_{1}+0.304 \cdot x_{3}+0.059 \cdot y_{4} \\
Y_{2}=0.156 \cdot x_{1}+0.164 \cdot x_{3}+0.417 \cdot x_{4}+1.94 \cdot y_{3}+0.331 \cdot y_{4}+1.054 \cdot y_{1} \\
Y_{3}=0.797 \cdot x_{1}+0.24 \cdot x_{2}+0.424 \cdot x_{5} ; \\
Y_{4}=0.53 \cdot x_{1}+0.615 \cdot x_{2}+0.389 \cdot x_{5}+0.471 \cdot y_{2} .
\end{array}\right.
$$

There is no only index that shows the degree of adequacy of the model over real data [14]. There are various indexes that give an idea of the adequacy of the model from different points of view. In fig. 4 the point indexes are given, the upper and lower are bounds of confidence intervals for the Steigar-Linde index and McDonald's noncentrality index are given. 


\begin{tabular}{|l|r|r|r|}
\hline \multirow{2}{*}{} & \multicolumn{3}{|c|}{ Noncentrality Fit Indices (диплом топ 10 } \\
\cline { 2 - 4 } & \multicolumn{1}{|c|}{ Lower 90\% } & Point & Upper 90\% \\
& Conf. Bound & Estimate & Conf. Bound \\
\hline Population Noncentrality Parameter & 0,000 & 0,356 & 1,502 \\
\hline Steiger-Lind RMSEA Index & 0,000 & 0,149 & 0,306 \\
\hline McDonald Noncentrality Index & 0,472 & 0,837 & 1,000 \\
\hline
\end{tabular}

Fig. 4. Model Adequacy indexes

The Steigan-Linda criterion closeness to zero (0.149) shows the satisfactory selection of the model. The McDonald's index (0.837) indicates a fairly high quality of the model, since the value obtained is close to the critical one (0.95).

All indexes indicate that the model is adequate. Analyzing the results obtained, one can conclude that the personality and innovation characteristics of the manager have the greatest influence on the efficiency of the personnel. Profit is influenced by gross investments and number of clients, and social position is significantly influenced by manager's characteristics. The amount of funds attracted is also influenced by personal characteristics. From the regression equation of the efficiency of the banking institution, it is clear that all variables that are included in it, have approximately the same effect, but nevertheless, the most significant is the communicative characteristic. The obtained modeling results confirm the hypothesis that for the investigated bank, structural unit managers need to work on the development of their communicative, innovative, personal and social characteristics.

Step 2 - Models of personnel motivation factors analysis based on factor analysis methodology. This stage involves the construction of analysis models of bank staff motivation factors. To implement this step, the following task was set and solved: to analyze and group the features that have the most influence on motivation of the personnel, to group them for further acceptance of managerial decisions. Analysis of literary sources [2, 4, $10-12,15]$ allowed to identify 13 characteristics that affect motivation of the bank employees, are given in Table 1.

Table 1

List of key staff motivation indicators

\begin{tabular}{|c|c|c|c|}
\hline Symb. & Characteristic & Symb. & Characteristic \\
\hline $\mathrm{X} 1$ & $\begin{array}{llr}\begin{array}{l}\text { Surcharges } \\
\text { conditions }\end{array} & & \\
\end{array}$ & $\mathrm{X} 8$ & $\begin{array}{l}\text { Trips costs for workers and members } \\
\text { of their families for treatment and rest, } \\
\text { excursions }\end{array}$ \\
\hline $\mathrm{X} 2$ & $\begin{array}{l}\text { Supplements and surcharges } \\
\text { to the rate and salary }\end{array}$ & X9 & Growth of the wage fund \\
\hline $\mathrm{X} 3$ & $\begin{array}{l}\text { One-time payouts for service } \\
\text { years }\end{array}$ & $\mathrm{X} 10$ & Financial aid for health improvement \\
\hline $\mathrm{X} 4$ & Bonus for results achieved & $\mathrm{X} 11$ & $\begin{array}{l}\text { Compensation for loss wages } \\
\text { (associated with wages indexation and } \\
\text { payment periods violation) }\end{array}$ \\
\hline $\mathrm{X} 5$ & $\begin{array}{l}\text { Incentive and Compensation } \\
\text { Payments }\end{array}$ & $\mathrm{X} 12$ & $\begin{array}{l}\text { Loans given to employees for } \\
\text { improving living conditions and } \\
\text { individual housing }\end{array}$ \\
\hline $\mathrm{X} 6$ & $\begin{array}{l}\text { Surcharges Coefficient of } \\
\text { staff performance, reflecting } \\
\text { the quality and work } \\
\text { performance }\end{array}$ & $\mathrm{X} 13$ & $\begin{array}{l}\text { Preventive measures for warning and } \\
\text { reduce morbidity with temporary } \\
\text { disability }\end{array}$ \\
\hline $\mathrm{X} 7$ & Loans to company employees & & \\
\hline
\end{tabular}

Among the above mentioned features, the factors that most influence motivation of the personnel are identified, using the methodology of factor analysis, namely the method of the main 
components, which is used to reduce the space dimension of the observed vectors, without causing a significant loss of informativity [14]. The solution to this isues is realized in the package STATISTICA $[1,14]$. The number of major factors that can be obtained by scree test presented in Fig. 5.

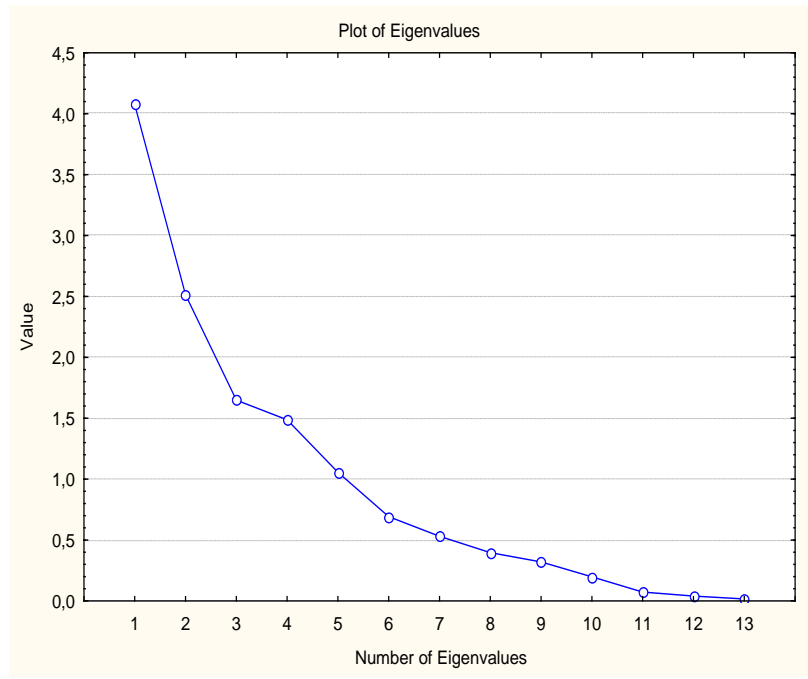

Fig. 5. Scree Test (Plot of Eigenvalues)

\begin{tabular}{|c|c|c|c|}
\hline \multirow[b]{2}{*}{ Variable } & \multicolumn{3}{|c|}{$\begin{array}{l}\text { Factor Loadings (Equamax raw) (S } \\
\text { Extraction: Principal components } \\
\text { (Marked loadings are }>, 600000 \text { ) }\end{array}$} \\
\hline & \begin{tabular}{|c|} 
Factor \\
1 \\
\end{tabular} & $\begin{array}{c}\text { Factor } \\
2\end{array}$ & $\begin{array}{c}\text { Factor } \\
3 \\
\end{array}$ \\
\hline$x 1$ & 0,597028 & $-0,528418$ & $-0,309751$ \\
\hline$\times 2$ & 0,691231 & $-0,339243$ & 0,005391 \\
\hline$\times 3$ & 0,000049 & 0,695511 & 0,183293 \\
\hline$\times 4$ & 0,875325 & $-0,220738$ & $-0,228759$ \\
\hline$\times 5$ & 0,912406 & 0,208499 & 0,181485 \\
\hline$x 6$ & 0,492132 & 0,195862 & $-0,270423$ \\
\hline$\times 7$ & 0,160125 & 0,672496 & 0,261771 \\
\hline$x 8$ & 0,004136 & 0,271960 & 0,725511 \\
\hline$\times 9$ & $-0,264898$ & 0,421282 & 0,002900 \\
\hline$\times 10$ & 0,111472 & 0,188354 & 0,815349 \\
\hline$\times 11$ & 0,644143 & 0,102959 & 0,283064 \\
\hline$x 12$ & $-0,432308$ & 0,797630 & $-0,188785$ \\
\hline$\times 13$ & 0,816813 & 0,324935 & $-0,092589$ \\
\hline Expl.Var & 4,052363 & 2,500170 & 1,671998 \\
\hline Prp.Totl & 0,311720 & 0,192321 & 0,128615 \\
\hline
\end{tabular}

Fig. 6. Factor loading (rotating Eguamax raw)

According to this plot, the number of newly created factors was equal 3. In the course of the study, all types of rotation were performed, and further calculations were made with Eguamax raw rotation shown in Fig. 6, because at this rotation the sum of Prp.Totl $=0.63$ values is maximal. The relation of features to one of the groups is carried out at a level of significance greater than 0.6 [14].

Consequently, by the main components method, we received 3 main factors that contain a certain set of primary indicators. The grouping table and the interpretation of the factor space are presented in Table 2.

Table 2

Grouping and factor space interpretation table

\begin{tabular}{|c|c|c|}
\hline Main factor & Indicator & Factor space interpretation \\
\hline \multirow{5}{*}{$\begin{array}{l}\text { Factor } 1(\mathrm{~F} 1) \\
\text { financial incentives } \\
\text { for employees }\end{array}$} & $\mathrm{x} 2$ & \multirow{5}{*}{$\begin{array}{l}\text { Supplements and surcharges to the rate and salary, } \\
\text { bonuses for achieved results, incentive and } \\
\text { compensation payments, compensation for loss wages } \\
\text { (associated with wages indexation and payment } \\
\text { periods violation), preventive measures for warning } \\
\text { and reduce morbidity with temporary disability }\end{array}$} \\
\hline & $\mathrm{x} 4$ & \\
\hline & $\mathrm{x} 5$ & \\
\hline & $\mathrm{x} 11$ & \\
\hline & $\mathrm{x} 13$ & \\
\hline \multirow{3}{*}{$\begin{array}{l}\text { Factor } 2(\mathrm{~F} 2) \\
\text { social incentives for } \\
\text { employees }\end{array}$} & x3 & \multirow{3}{*}{$\begin{array}{l}\text { One-time payouts for service years, loans to company } \\
\text { employees, loans given to employees for improving } \\
\text { living conditions and individual housing }\end{array}$} \\
\hline & x7 & \\
\hline & x12 & \\
\hline \multirow{2}{*}{$\begin{array}{l}\text { Factor } 3(\mathrm{~F} 3) \\
\text { medical insurance for } \\
\text { employees }\end{array}$} & x8 & \multirow{2}{*}{$\begin{array}{l}\text { Trips costs for workers and members of their families } \\
\text { for treatment and rest, excursions, financial aid for } \\
\text { health improvement }\end{array}$} \\
\hline & $\mathrm{x} 10$ & \\
\hline
\end{tabular}

Evaluating process of main components informativeness level are presented in Table 3. 
Table 3

Values of weight coefficients and informativeness coefficient

\begin{tabular}{|c|c|c|c|c|c|c|c|}
\hline Variable & $F 1$ & $F 2$ & $F 3$ & Variable & $F 1$ & $F 2$ & $F 3$ \\
\hline $\mathrm{x} 1$ & 0,597028 & $-0,528418$ & $\begin{array}{c}- \\
0,309751\end{array}$ & $\mathrm{x} 8$ & 0,004136 & 0,271960 & 0,725511 \\
\hline $\mathrm{x} 2$ & 0,691231 & $-0,339243$ & 0,005391 & $\mathrm{x} 9$ & $\begin{array}{c}- \\
0,264898\end{array}$ & 0,421282 & 0,002900 \\
\hline $\mathrm{x} 3$ & 0,000049 & 0,695511 & 0,183293 & $\mathrm{x} 10$ & 0,111472 & 0,188354 & 0,815349 \\
\hline $\mathrm{x} 4$ & 0,875325 & $-0,220739$ & - & $\mathrm{x} 11$ & 0,644143 & 0,102959 & 0,283064 \\
\hline $\mathrm{x} 5$ & 0,912406 & 0,208499 & 0,181485 & $\mathrm{x} 12$ & - & 0,797629 & - \\
\hline $\mathrm{x} 6$ & 0,492132 & 0,195862 & - & $\mathrm{x} 13$ & 0,816813 & 0,324935 & - \\
& & & 0,270423 & & & & 0,092589 \\
\hline $\mathrm{x} 7$ & 0,160125 & 0,672496 & 0,261771 & $\mathrm{k}$ & 0,779442 & 0,628837 & 0,712417 \\
\hline
\end{tabular}

The indicators informativeness for $\mathrm{x} 2, \mathrm{x} 4, \mathrm{x} 5, \mathrm{x} 11, \mathrm{x} 13$, which determine the first major factor F1 by coefficient of informativity is 78\%. Informativeness of the main factor F2 (x3, x7, $\mathrm{x} 12$ ) by the coefficient of informativeness is $63 \%$, factor F3 (x8, x10) $-71 \%$. The obtained factor equations can be written as follows:

$$
\begin{aligned}
& F_{1}=0.691 \cdot x_{1}+0.875 \cdot x_{4}+0.912 \cdot x_{5}+0.644 \cdot x_{11}+0.817 \cdot x_{13} \\
& F_{2}=0.695 \cdot x_{3}+0.672 \cdot x_{7}+0.797 \cdot x_{12} \\
& F_{3}=0.725 \cdot x_{8}+0.815 \cdot x_{10} .
\end{aligned}
$$

From the regression equations it is noticeable that the greatest influence on the first factor (financial incentives for employees) makes the variable $\mathrm{x} 5$ - incentive and compensation payments. The second factor (social incentives for employees) extent depends on the indicator x12 - loans given to employees for improving living conditions and individual housing. The third factor (medical insurance for employees) is more strongly influenced by the indicator $\mathrm{x} 10$ - financial aid for health improvement. These data can be used by managers if they are to choose which variables need to be changed in order to get the most effective result from motivation.

Step 3 - Estimation model of motivation factors influence on bank's activity results based on nonlinear econometric modeling. This stage involves the assessment of the factors impact on the overall performance, namely on the dynamics of the bank's profit. Using the regression equations (3) obtained in step 2, we can find the estimated values of the motivational factors F1, F2, F3, which are graphically presented in Fig. 7, which also shows the bank profit (PB).

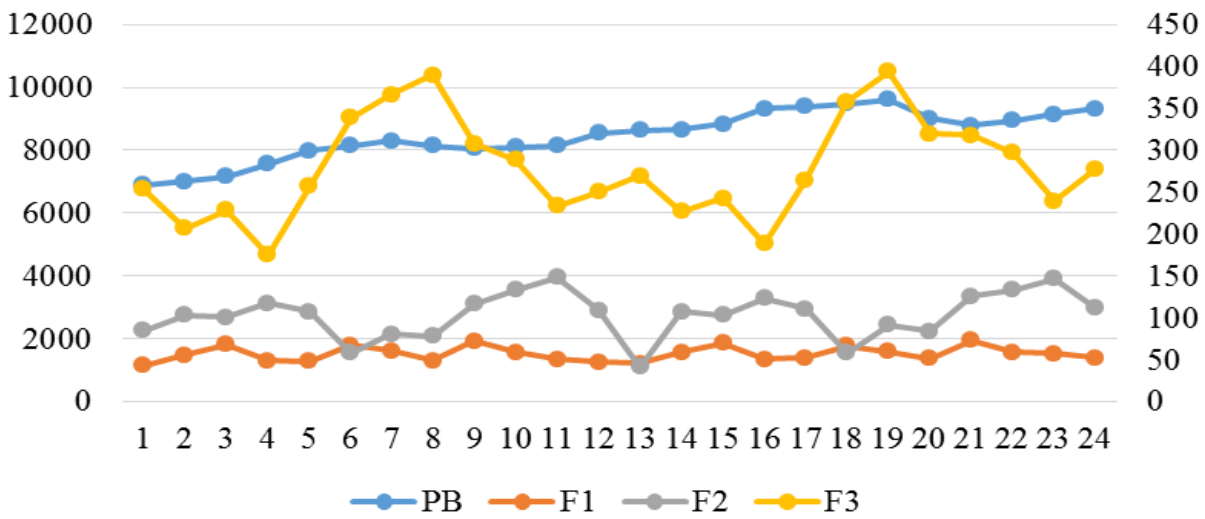

Fig. 7. Diagram of the bank’s motivational factors and profit 
As a construction result of various types of econometric models for dependence between the investigated indicators and factors, the most adequate results are obtained by nonlinear models (Fig. 8).

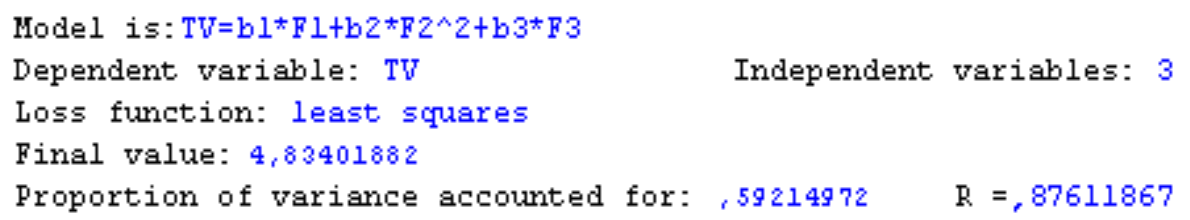

Fig. 8. Window of non-linear modeling analysis results

Interpreting the results of the study is as follows:

- Final Value shows a final modeling error that should be close to 0 (the smaller error the better model);

- Proportion of variance accounted - the percentage of variance explanation, it is desirable that it was not less than 0.5 . In our case, the percentage of variance explanation is equal 0.59;

- The R-correlation ratio varies in the range from 0 to 1 . In our case, $\mathrm{R}=0.87$, it is close to 1, indicating a high level of the model adequacy [14].

In fig. 9 shows the coefficients of nonlinear regression, their errors, significance according to Student's criterion and coefficients interval estimates.

\begin{tabular}{|c|c|c|c|c|c|c|}
\hline & \multicolumn{6}{|c|}{$\begin{array}{l}\text { Model is: TV=b1*F1+b2*F2^2+b3*F3 (последние данные) } \\
\text { Dep. Var. : TV } \\
\text { Level of confidence: } 95.0 \% \text { (alpha=0.050) }\end{array}$} \\
\hline & Estimate & $\begin{array}{c}\text { Standard } \\
\text { error }\end{array}$ & $\begin{array}{l}\text { t-value } \\
\mathrm{df}=21\end{array}$ & p-level & $\begin{array}{l}\text { Lo. Conf } \\
\text { Limit }\end{array}$ & $\begin{array}{l}\text { Up. Conf } \\
\text { Limit }\end{array}$ \\
\hline b1 & 1,99397 & 0,889363 & 22,242016 & 0,035887 & 0,144435 & 3,84350 \\
\hline b2 & 0,17000 & 0,000062 & 32,691006 & 0,013680 & 0,020038 & 0,21430 \\
\hline b3 & 14,26927 & 3,979007 & 33,586138 & 0,001740 & 5,994468 & 22,54406 \\
\hline
\end{tabular}

Fig. 9. Values of the non-linear regression coefficients

From the obtained results, we conclude that all parameters are statistically significant according to Student's criterion and have small errors, which confirms the adequacy of modeling of real process. The obtained regression equation has the following form:

$$
P B=1.994 \cdot F_{1}+0.17 \cdot\left(F_{2}\right)^{2}+14.27 \cdot F_{3} .
$$

Consequently, in order to increase the competitiveness of banks and increase productivity of employees, management of banks should implement a stable and timely material incentive; encouraging the improvement of skills, qualifications of employees; accounting of individual features of employee motivation; providing self-development opportunities; certain autonomy of employees; respect for the personality of employees, encouraging employees to find new, promising ideas for improving activities and material (moral) encouragement of creativity in the workplace.

Conclusions. The economic processes that take place in banking business under conditions of a market economy are characterized not only by the dynamics of the flow, but also by the large number and variability of factors that are closely related to the management of the staff. Thus, by ensuring the bank's efficiency through professional knowledge and skills, professionalism and innovation staff are indeed a significant strategic development resource. The proposed methodological aspects of the evaluation of the effectiveness of the organization of personnel management and motivation, realized on the basis of the use of methods of mathematical modeling, prove that the introduction of special regulations for staff for all bank services, continuous and effective monitoring of the professional development of employees by management, the development of effective methods of motivation and raising the level of education is a necessary component for increasing the competitiveness of the bank. 


\section{Література:}

1. Боровиков В. П. STATISTICA: искусство анализа данных на компьютере. Для профессионалов / В. П. Боровиков. - Санкт Петербург : Питер, 2001. - 656 с.

2. Винокур Л. І. Закордонний та вітчизняний досвід становлення методології управління персоналом в банківській сфері / Л. І. Винокур, С. С. Полях // Фінансовий простір. — 2016. — № 2 (22). — С. 7 -12.

3. Гетьман О. О. Особливості механізму стимулювання персоналу в банківській сфері / О. О. Гетьман, Є. О. Киричок // Бізнес Інформ. - 2015. - № 4. - С. 279-283.

4. Голофаєва І. П. Управління фінансовою безпекою комерційного банку на основі потокових сценарних моделей / І. П. Голофаєва, О. А. Сергієнко, Я. Ю. Солдатова // Бізнес Інформ. — 2014. — № 12. — С. 237—247.

5. Григор'єв О. Ю. Удосконалення мотивування працівників вітчизняних підприємств на засадах впровадження системи Грейдів / О. Ю. Григор'єв, О. Г. Мельник, О. В. Денисюк // Вісник Національного університету «Львівська політехніка». Менеджмент та підприємництво в Україні: етапи становлення і проблеми розвитку. — 2015. — № 835. — С. $56-62$.

6. Ізюмцева Н. В. Особливості побудови мотиваційного процесу в банку (на прикладі ПАТ КБ «ПриватБанк») / Н. В. Ізюмцева, Р. І. Коршунов // Бізнес Інформ. — 2017. — № 11. — С. 472—477.

7. Ізюмцева Н. В. Організація системи мотивації банківського персоналу в умовах посткризового розвитку економіки / Н. В. Ізюмцева, Г. В. Мирончук // Вісник Університету банківської справи Національного банку України. 2012. — № 1. - С. 279-283.

8. Карпінський Б. А. Синергетика: еволюція поглядів та прояв управлінських рішень у фінансово-економічному просторі. Ч. І / Б. А. Карпінський, В. О. Григоренко // Науковий вісник НЛТУ України : зб. наук.-техн. пр. — Львів : РВВ НЛТУ України, 2013. - Вип. 23.17. - С. 366-375.

9. Карпінський Б. А. Синергетика: еволюція поглядів та прояв управлінських рішень у фінансово-економічному просторі. Ч. ІІ / Б. А. Карпінський, В. О. Григоренко // Науковий вісник НЛТУ України : зб. наук.-техн. праць. — Львів : РВВ НЛТУ України, 2013. - Вип. 23.18. - С. 252-259.

10. Косова Т. Д. Банківські операції: навчальний посібник : для студ. ВНЗ / Т. Д. Косова, О. Р. Циганов ; Мін-во освіти і науки України, Донецький державний ун-т управління. — Київ : ЦУЛ, 2008. — 372 с.

11. Кульков С. В. Некоторые проблемы системы мотивации персонала региональных коммерческих банков и пути их решения / С. Кульков // Управление персоналом. — 2008. — № 7. - С. 29-35.

12. Нікітін Ю. О., Рукас-Пасічнюк В. Г. Сучасні моделі та механізми мотивації персоналу українських підприємств / Нікітін Ю. О., Рукас-Пасічнюк В. Г. // Актуальні проблеми економіки : науковий економічний журнал. - 2014. - № 4 (154). - C. $238-246$.

13. ПАО «Укрсоцбанк» України: офіційний сайт [Електронний ресурс]. - Режим доступу: https://ru.ukrsotsbank.com.

14. Халафян А. A. STATISTICA 6.0. Статистический анализ данных: учебник / А. А. Халафян. - 3-е изд. Москва : ООО «Бином-Пресс», 2007. - 512 с.

15. Череп А. В. Теоретико-методичні підходи до визначення ефективності праці персоналу комерційного банку / А. В. Череп, О. Г. Череп // Сталий розвиток економіки: Науково-виробничий журнал. — 2011. — № 3. — С. 259 - 264.

Стаття рекомендована до друку 10.12.2018

(C) Сергієнко О.А., Морозова Н.Л., Карпець О.С., Бабенко М.В.

\section{References}

1. Borovykov, V. P. (2001). STATISTICA: iskusstvo analiza dannyh na komp'yutere. Dlya professionalov. Saint Petersburg: Piter [in Russian].

2. Vynokur, L. I., \& Polyakh, S. S. (2016). Zakordonnyi ta vitchyznianyi dosvid stanovlennia metodolohii upravlinnia personalom $\mathrm{v}$ bankivskii sferi [Foreign and domestic experience of establishing a methodology for personnel management in the banking sector]. Finansovyi prostir — Financial Space, 2 (22), 7 - 12 [in Ukrainian].

3. Hetman, O. O., \& Kyrychok, Ye. O. (2015). Osoblyvosti mekhanizmu stymulyuvannia personalu v bankivskii sferi. Biznes Inform — Business Inform, 4, 279-283 [in Ukrainian].

4. Holofayeva, I. P., Serhiyenko, O. A., \& Soldatova, Ya. Yu. (2014). Upravlinnya finansovoyu bezpekoyu komertsiynoho banku na osnovi potokovykh stsenarnykh modeley [Managing financial security of a commercial bank based on streaming scenario models]. Biznes Inform — Business Inform, 12, 237 — 247 [in Ukrainian].

5. Hryhoriev, O.Yu., Melnyk, O. H., \& Denysiuk, O.V. (2015). Udoskonalennya motyvuvannya pratsivnykiv vitchyznianykh pidpryiemstv na zasadakh vprovadzhennia systemy Hreidiv [Improvement of motivation of employees of domestic enterprises on the basis of the introduction of the Graduate system]. Visnyk Natsionalnoho universytetu «Lvivska politekhnika». Menedzhment ta pidpryyemnytstvo v Ukrayini: etapy stanovlennya i problemy rozvytku — Bulletin of the Lviv Polytechnic National University. Management and Entrepreneurship in Ukraine: Stages of Development and Development Issues, 835, 56-62 [in Ukrainian].

6. Izyumtseva, N. V., \& Korshunov, R. I. (2017).Osoblyvosti pobudovy motyvatsiynoho protsesu v banku (na prykladi PAT KB «PryvatBank») [Features of building a motivational process in a bank (for example, PJSC CB "PrivatBank")]. Biznes Inform — Business Inform, 11, 472-477 [in Ukrainian].

7. Izyumtseva, N. V., \& Myronchuk, H. V. (2012). Orhanizatsiya systemy motyvatsiyi bankivs'koho personalu v umovakh postkryzovoho rozvytku ekonomiky [Organization of the system of motivation of banking personnel in the conditions of post-crisis economic development] // Visnyk Universytetu bankivskoyi spravy Natsionalnoho banku Ukrainy - Bulletin of the University of Banking of the National Bank of Ukraine, 1, 279-283 [in Ukrainian].

8. Karpinskyi, B. A., \& Hryhorenko, V. O. (2013). Synerhetyka: evolyutsiya pohlyadiv ta proyav upravlins'kykh rishen' u finansovo-ekonomichnomu prostori. Ch. I [Synergetics: evolution of views and manifestation of managerial decisions in the financial and economic space. P. 1]. Naukovyy visnyk NLTU Ukrainy : zb. nauk.-tekhn. prats. — Scientific Bulletin of NLTU of Ukraine: Sb. Sci.-Tech. ave., 23.17, 366-375. Lviv : RVV NLTU Ukrainy [in Ukrainian]. 
9. Karpinskyi, B. A., \& Hryhorenko, V. O. (2013). Synerhetyka: evolyutsiya pohlyadiv ta proyav upravlins'kykh rishen' u finansovo-ekonomichnomu prostori. Ch. 2 [Synergetics: evolution of views and manifestation of managerial decisions in the financial and economic space. P. 2]. Naukovyy visnyk NLTU Ukrainy : zb. nauk.-tekhn. prats. — Scientific Bulletin of NLTU of Ukraine: Sb. Sci.-Tech. ave., 23.18, 252-259 [in Ukrainian].

10. Kosova, T. D., \& Tsyhanov, O. R. (2008). Bankivski operatsii: navchalnyi posibnyk : dlya stud. VNZ [Banking Transactions: Textbook: for undergraduate students]. Kyiv: TSUL [in Ukrainian].

11. Kul'kov S. V. (2008). Nekotorye problemy systemy motyvatsyy personala rehyonal'nykh kommercheskykh bankov y puty ykh reshenyya [Some problems of system of motivation of personnel of regional commercial banks and ways of their decision].Upravlenye personalom — Human Resources Management , 7, 29—35 [in Russian].

12. Nikitin, Yu.O., \& Rukas-Pasichnyuk, V. H. (2014). Suchasni modeli ta mekhanizmy motyvatsiyi personalu ukrayins'kykh pidpryyemstv [Modern models and mechanisms of motivation of personnel of Ukrainian enterprises]. Aktual'ni problemy ekonomiky: naukovyy ekonomichnyy zhurnal — Actual problems of economy: scientific economic journal, 4 (154), 238246 [in Ukrainian].

13. PAO "Ukrsotsbank" Ukrayiny: ofitsiynyy sayt [PJSC "Ukrsotsbank" of Ukraine: official site]. (n. d.). ukrsotsbank.com. Retrieved from https://ru.ukrsotsbank.com/ [in Ukrainian].

14. Khalafyan, A. A. (2007). STATISTICA 6.0. Statystycheskyy analyz dannykh: uchebnyk [STATISTICA 6.0. Statistical data analysis: tutorial]. Moscow: OOO «Bynom-Press».

15. Cherep, A.V., \& Cherep, O. H. (2011). Teoretyko-metodychni pidkhody do vyznachennya efektyvnosti pratsi personalu komertsiynoho banku [Theoretical and methodical approaches to determination of labor efficiency of the personnel of a commercial bank]. Stalyy rozvytok ekonomiky: Naukovo-vyrobnychyy zhurnal — Sustainable Economic Development: Scientific and Production Magazine, 3, 259—264 [in Ukrainian].

The article is recommended for printing 10.12 .2018

(C) Sergienko O., Morozova N., Karpets O., Babenko M. 